\title{
Anthrovision
}

Vaneasa Online Journal

Vol. $7.1 \mid 2019$

Aesthetic Encounters

\section{A Journey from Virtual and Mixed Reality to Byzantine Icons via Buddhist Philosophy}

Possible (Decolonizing) Dialogues in Visuality across Time and Space

Paolo S. H. Favero

\section{(2) OpenEdition}

\section{Journals}

Electronic version

URL: http://journals.openedition.org/anthrovision/4921

DOI: 10.4000/anthrovision.4921

ISSN: 2198-6754

\section{Publisher}

VANEASA - Visual Anthropology Network of European Association of Social Anthropologists

\section{Electronic reference}

Paolo S. H. Favero, «A Journey from Virtual and Mixed Reality to Byzantine Icons via Buddhist Philosophy », Anthrovision [Online], Vol. 7.1 | 2019, Online since 11 March 2020, connection on 12 November 2020. URL : http://journals.openedition.org/anthrovision/4921 ; DOI : https://doi.org/ 10.4000/anthrovision. 4921

This text was automatically generated on 12 November 2020 .

(c) Anthrovision 


\title{
A Journey from Virtual and Mixed Reality to Byzantine Icons via Buddhist Philosophy
}

Possible (Decolonizing) Dialogues in Visuality across Time and Space

\author{
Paolo S. H. Favero
}

From Asia to America, Europe to the Middle East we are today witnessing to the shaping up of a world progressively more and more devoted to separation. Borders, walls and fences are being rebuilt, identities reconstructed in terms of principles of exclusion enacted at the expenses of those who are forced to migrate. Societies and cultures are increasingly being envisioned as 'walled' (Khosravi 2018) and calls for the rights of those who 'were there first' are dominating the debates of many rich countries. In this movement, 'self' and 'other' are pulled apart and unity is becoming a chimera, slowly appearing as a ghost from a distant past. We have no doubt entered post-globalization, an era of separation between countries, individuals and between ourselves and what surrounds us. In parallel to these dramatic changes we are however witnessing to a counter-tendency, located mainly in the world of emerging technologies, of digital visual image-making practices. The popularity of virtual, mixed ${ }^{1}$ and augmented reality (from here onwards VR, MR and AR) of 360 degree and other forms of life-logging and plenoptic image-practices seem to pull in the opposite direction. They speak of a desire (simultaneously new and ancient) for unity, for trespassing of the divide between 'self' and 'other', 'self' and the world. Such desire runs as a continuum in the history of art across time and place, and images today are more than ever an expression of this. Claiming their right to become an active part in our lives, images have abandoned the dominating duty to exclusively portray and represent, entering instead a terrain dominated by notions of 'presencing' and empathy, of contemplation and transformation. In line with what Wassily Kandinsky (1989) wrote long ago with reference to the duty of art, 'present images' (Favero 2018, see below) seem to be less interested in mirroring the world than in functioning as a prophecy, of providing us with a beacon for a different way of visualising and approaching the world in which we live. This article aims to address this shift and the 
conceptual continuity that underpins it. Focussing on the world of VR and MR art and documentary practices, I aim to offer insights into the possible exchanges (conscious and not) that make up their present existence, functioning and meaning. Through an approach aiming at 'decolonizing' knowledge I will in this text juxtapose these hypermodern, 'avant-gardish' late-capitalist, image-making practices with an ancient, premodern visuality, that of the painted (Byzantine) icon. The debate on the decolonisation of film canons and visual culture is today indeed a leading topic in the social sciences and humanities. I believe that it is important to push this approach beyond the mere analysis and observation of 'other', 'non-Western' ways of entering the visual field (which often occurs within the space of Western hegemonic visuality). Instead, turning this position upside down, we should aim at incorporating into our analysis of Western, late-capitalist visual practices those epistemological assumptions that underpin other' visualities. My attempt is to explore the extent to which the insights gathered from the analysis of the visuality of Byzantium (but also Hindu) icons can help us enact a grounded rethinking of the assumptions that guide hegemonic (Western) approaches to the world of images and especially of emerging digital visual worlds. The reflections on Buddhist epistemology that I will insert in this paper take this challenge further attempting at showing the extent to which the introduction of a different epistemology can provide us with a new language for analysing and describing this emerging terrain. Underpinning my analysis is also a claim of continuity in ambition in the field of immersive images. VR and MR express, albeit by means of different techniques, a similar desire for immersion of that which characterizes other (more ancient) visual regimes. As a consequence, the images that circulate in contemporary digitised habitats, rather than taking us into a futuristic unknown territory can also help us to re-centralise, by means of the digital, ways of engaging with visual representations that can be found elsewhere and 'elsewhen.'

This article will begin with a brief portrait of the contemporary worlds of digital visualities. I will then proceed to offer two examples from what I consider to be revealing VR/MR experiences. From there I will proceed to analyse the visuality that characterises religious icons and, finally, reflect upon the dialogues across these different visualities. My hope is that these passages may help us looking at contemporary, digitally produced, emerging arts and documentary visual practices with new eyes. ${ }^{2}$

\section{Background}

3 A quick look into the broader contemporary (digital) world of image-making, imageviewing and images-sharing practices shows how images today emerge as being much more than matters of representation and narration. From Facebook to Instagram, from 3D printing to VR, MR, and AR images seem to do much more than 'illustrating,' 'reflecting,' or 'capturing' the world out there. They rather concur in its very crafting. The images travelling in contemporary digital habitats create relations and materialities. They are increasingly multisensory and participated hence stitching together users with each other and with the world that surrounds them. A banal example could be the images that circulate on Facebook. Loaded with metadata indicating when and where and with whom they were taken, and augmented also by a large amount of written and visual dialogues, such images materialise communities and 
life-trajectories. If we once upon a time addressed the act of making pictures (or more specifically of taking photographs) as an act of killing,as Barthes (1993) would have it, or of preserving the past for posterity - for example Bazin's (1960) idea of photographs as being obsessed by a 'mummy complex'- images seem today to cling onto the present moment. As Mizuko Ito (2005) anticipated long ago in her path-breaking essay on MMSs, images are calling for 'visual co-presence.' They are increasingly made to share the present of the image-maker with that of a viewer located elsewhere. Images are 'present' in today's digital habitats, I have recently suggested (Favero 2018); they simultaneously foreground 'presence' and the present moment.

With the arrival of digital technologies images have therefore become more than ever paradoxical objects. They are invested by a duty of doing many (and at times contradictory) things at once: of representing and presenting, of presencing, crafting and connecting. This ambition, I would like to suggest, is, however, far from unique to our epoch. In many cultural contexts (of the past as well of the present, here as well as in faraway places) images have had this function. In Antiquity, as well in many religious contexts, images often functioned as portals, two-way gates allowing an exchange between human beings and the world surrounding them. In relation to Byzantineinspired imagery, for instance, Russian monk, art historian and theologian Pavel Florensky (1977) wrote, in the early nineteenth century, that an image is 'not only a window through which the visages depicted in them appear, but also a gate from which these enter the sensible world' (Florensky 1977: 69). And in the context of Aboriginal Australia, Elizabeth Edwards (2005) has shown how photographs function as relational objects. Central to the act of articulating histories that have been suppressed, photographs constitute an element in a much broader performance. They are held, caressed, stroked, sung: they become sound, the sounds of voices, of songs, of memories verbalised as stories; an oral history materialising the relationships between specific individuals who engage each other through such images. They are 'things that matter' (Edwards 2005: 28) not just visual depictions. Similarly, in the context of Hindu devotional practices too, representations of the Gods are considered to be direct emanations of God. As implied in the notion of darshan, the act of looking is, in this context, an act of being looked at, an on-going inter-penetration leading to a full immersion in the image. As Diana Eck (1998) expresses it: "because the image is a form of the supreme lord, it is precisely the image that facilitates and enhances the close relationship of the worshipper and God and makes possible the deepest outpouring of emotions in worship' (Eck 1998: 46). They are guided by the logic of what Christopher Pinney has called 'corpothetics' (2001), i.e. an 'embodied, corporeal aesthetics' which stands in opposition 'to "disinterested" representation, which over-cerebralizes and textualizes the image' (Pinney 2001:8). They hence foreground efficacy and presence rather than realist representation and associate the act of seeing to that of touching. As Lawrence Babb (1981) suggests, seeing is in this context an 'outward-reaching process' (Babb 1981: 393) that directly engages the object seen. Seeing is a material exchange between the viewer and the viewed, one involving not just the eyes but the whole body. One becomes 'what one sees' (Babb 1981: 297) in an act that could probably be inserted within the logic of 'contagion' and hence of ('sympathetic') magic (Frazer 2009).

5 I want to claim however that these parallel visualities have been sidelined, especially in the West, by hegemonic narratives of realist representation and by linguistic reductions. Starting from the latter, Barbara Maria Stafford (1996) in her writings 
about surfaces attacks the 'totemization of language as a godlike agency' (Stafford 1996: 5) that characterizes Western culture. She suggests that Saussure's schema 'emptied the mind of its body' reducing images to 'encrypted messages requiring decipherment' (Stafford 1996: 6). ${ }^{3}$ Regarding the latter, realist representation relies on the conventions that were established by Renaissance geometrical perspective. Grounded in the West's growing obsession with rationality, lines and mathematics, and mirroring Descartes hierarchization of the relation between the senses and the intellect, geometrical perspective came to constitute, to use Martin Jay's (1988) terms, a 'scopic regime,' i.e. a dominant theory of vision. Conventionally metaphorized with the help of a window allowing to measure a particular view, perspective created a strict separation between the observer and the observed, the self and the world. 'Pushing' the viewers out of the image, it made reciprocity impossible allowing them instead to control the image (rather than to situate themselves within it). While not representing the complete spectrum of images produced by Western artists (below I will go further in depth with this by means of a number of examples) I still claim that geometrical perspective constitutes a kind of hegemony, to use a Gramscian (1971) term, that has progressively marginalized other kinds of approaches to the world of images. It is true then, in line with what Georges Didi-Huberman (2003) said, 'we ask too little of images' Didi-Huberman 2003: 33). In order to explore this further let me now offer a couple of examples gathered form the world of contemporary art and documentary.

\section{VR and MR Art and Documentary}

6 VR, MR and 360-degree images are today emerging with a broad appeal. They are employed in commercial, artistic and therapeutic settings increasingly exploring that space in between the 'actual' and the 'virtual' (Milgram et al. 1994).

Let me offer two examples. Draw Me Close is an MR 'experience' (this is the term used in the official presentation of the performance) authored by award-winning playwright and filmmaker Jordan Tannahill. ${ }^{4}$

This media file cannot be displayed. Please refer to the online document http:// journals.openedition.org/anthrovision/4921

Video link: https://www.youtube.com/watch?v=4zokAxgRNYs

This media file cannot be displayed. Please refer to the online document http:// journals.openedition.org/anthrovision/4921

Video link: https://www.youtube.com/watch?v=XrpUvRSb2E0

Using a combination of hand trackers and VR goggles this play is a one-on-one performance. One at a time the viewers are exposed, in a small room, to an intimate encounter, in VR, with the mother of the director who passed away of cancer when he was a young boy. The performance stages his distant memories through an actress wearing sensors. She stages live the movements and gestures that the viewers receive in the shape of black-and-white drawings in the VR goggles. I have never had a chance to experience the performance directly but have engaged with the testimonies of viewers. And indeed, I could not but notice the short-circuit that this experience 
generates in them. Entering a VR space filled with animated drawings viewers are suddenly asked to abandon the realm of 'real life' experience and enter that of simulated storytelling. This movement becomes at first tangible when the viewers are asked to draw on a canvas. Watching their own drawings become colourful traces within a simulated environment they start closing in the gap between the virtual and the actual. The real short-circuit happens, however, at a later moment, when the mother (the actress) eventually asks them whether she can hug them. A disrupting moment, this instance brings even further the virtual in direct contact with the actual, physically mediated experience, of the viewers' own bodies.

11 I experienced a similar short-circuiting when viewing 6X9, a VR experience produced by the British newspaper, The Guardian, and directed by Francesca Pennetta. ${ }^{5}$

This media file cannot be displayed. Please refer to the online document http:// journals.openedition.org/anthrovision/4921

Video link: https://www.youtube.com/watch?v=odcsxUbVyZA\&t=13s

13 A simulated experience of solitary confinement 6X9 inserts the viewers, upon entrance in the VR space, into a tiny, greyish room. When I entered this experience, I found myself sitting on a bed in one of the corners of the room. The room was only semi-lit but I could detect a few objects in the space. Opposite to me there was a door with a tiny window secured by metal bars. I do not remember all the details so clearly. However, I can recall that, at a certain point, I noticed the book and the magazine laying on a shelf next to me and that I heard voices coming in from the outside. As time passed by, being in the room became progressively disturbing. At one point, the room shook; the lights went off and on again. The voices I heard from outside the door became louder and more pervasive. The warning of a possible moment of panic started to rise in me: suffering from claustrophobia I was getting warm and started to sweat. By mistake I managed to interrupt that moment by touching the table in front of me in the room that was hosting the VR experience. 'Visible' only to my hands this table brought me into a kind of split: my hands and my eyes anchored me respectively in two different, perhaps parallel worlds. My mind and body complex was suddenly torn. Where was I or rather who and what was I? Where was my body now that the sweat really seemed to belong to the virtual space and my hands to the actual one? Was I the person wearing VR or the convict in the cell? Or maybe both? Should I trust my eyes or my hands?

14 Both these experiences seem to direct our attention to the space in between self and other, or better between self and not-self. Through the multiple short-circuits I described above we are interrogated about these boundaries and also led to reflect further also on our perception of the relation between body and mind, and on our awareness of the relativity of the self. Let me open a brief parenthesis here. I believe that in order to grasp such insights we ought to abandon the terrain of Western dualistic epistemologies. We may in fact get a better understanding by adopting the insights on perception that characterize for instance, Buddhist philosophy. ${ }^{6}$ It is not within the scope of this contribution to enter fully into this debate but let me only point out that the principle of non-duality or of double negation -which is one of the pillars of Buddhist thought (Shaw 1978)_ can help us addressing this in-between space, this being neither 'self' nor 'not-self'. Avoiding reductions to binary oppositions 
Buddhist philosophy suggests that between such opposite poles we may also contemplate the possibility of being simultaneously both 'self' and 'not-self' and also 'neither self' nor 'non-self'. Such resistance to binary reductions is key to the Buddhist (agnostic) way of addressing the world. Looking upon as an impermanent, fleeting object in constant becoming Buddhism engages with the world though a constant act of 'confrontation' (Batchelor 1997: 18) rather than through a search for solid, stable answers. Buddhism can hence be seen as a method rather than a coherent system of knowledge (von Glanesapp 1967, Tucci 1992, Batchelor 1997). Grounded in contingency and ambiguity, it builds on the recognition of transcendence and of the impossibility to fully know. As Batchelor suggests Buddhism 'offers no answers, only the possibility of new beginnings' (1997: 103). The logic of double negation inserts itself into this terrain, one where human perceptions of the world can neither be fully true nor false. Within this (circular) space 'I' can be simultaneously 'self' and 'not-self' and also 'neither self' nor 'non-self'. 'I' can be simultaneously 'here' and 'not-here'. I suggest that the application of these (consciously unstable) epistemological principles can help us grasp what happens in VR and MR, and help us address the various shifts in identification that make up the perception of many viewers. In such environments viewers are simultaneously neither 'self' nor 'not-self,' neither presence nor absence, neither 'body' nor 'not-body'. They engage in a processual (performative) 'confrontation' that eventually leads them to discover the fragmented nature of the self, the multisensory nature of human perceptions and the continuum that makes up the body-mind complex. An attempt at decolonizing our knowledge, enacted through the insertion of elements borrowed from other epistemologies, can provide new insights into this possibly 'uncanny' territory, where we discover experiences, to use Sigmund Freud's ([1919] 1925) definition of this term, that are 'strangely familiar' and hence both known and not-known.

15 The act of entering such image spaces entails also the abandonment to a curved, ephemeral, dynamic and shifting frame that is significantly different form the square frame that characterizes flat 2D images. Rather than an act of pure seeing, of grasping, and perhaps also of controlling a totality (as a perspectival image would allow us to do), such image-environments entail an act of acceptance of this totality, of becoming one with it, of abandoning any desire to dominate and also to understand. Such a stance brings back to our attention not only the Buddhist principles discussed above, but also Maurice Merleau-Ponty's (1962) intuition that 'man is in the world, and only in the world does he know himself' (Merleau-Ponty's 1962: xi). As Merleau-Ponty suggests in his description, such settings can lead viewers to realise that: 'I am neither here nor there, neither Paul nor Peter; I am in no way distinguishable from an 'other' consciousness, since we are immediately in touch with the world and since the world is, by definition, unique, being the system in which all truths cohere' (Merleau-Ponty's 1962: xi).

VR/MR experiences do evidently pose a number of challenges to conventional ways of approaching the world of images. In the first place these images are interactive; they are personal (hence marking a step away from 'mass' media) and multisensory (directing appealing to both vision, sound, movement and tactility). As I have suggested elsewhere (Favero 2018), such acknowledgement entails a rethinking also of a number of terms, on which the conventional terminology used for analysing images builds upon. For instance, how should we address the frame in a context where this has morphed away from that protective square that as in Albrecht Dürer's famous 
illustration of a perspectival frame (in The Painter's Manual, 1525), separated the viewer form the world, to become instead an embracing environment within which the viewers can move? How to speak of 'frames' when viewers are not external to (and hence no longer in control of) the visual field? And how can we approach the various ways in which images come to us in the absence of the beamer, that politically dense apparatus that, with its fixed point of emanation of light, reproduces the principles that informed Renaissance perspective? The result of a long evolution that started with the camera obscura, the magic lantern, the silhouette, and the cathode ray tube, projection is, in fact, far from neutral. I need not go further in depth with these questions, confident that the challenges that such digital visual practices pose to our conventional assumptions are quite evident.

\section{Parallel Visualities}

17 I want now to proceed further and address the extent to which the immersive desire expressed by such new images is far from unique to them and hence far from novel. Rather it is an insistent longing and appearing throughout the history of visual art and of image-making techniques and technologies. Let me first come out with a disclaimer. Despite addressing the continuity in attempts at immersing viewers in the image and hence at blurring the separation between spaces that we could address as being virtual and actual, my analysis makes no claim, as I anticipated in the introduction, at tracing a historical continuity of techniques. I believe, however, that such (parallel) visualities function both as concrete inspirational forces for contemporary VR artists and documentarians. They also express a desire, or ambition, or yearning that human beings, across places and times, have had in relation to the world of images, i.e. that of closing the gap, through the image, between themselves and the world. Let me offer a few examples of the different modalities through which this immersion has been obtained in the past.

In the Villa dei Misteri (House of Mysteries) in Pompei (Italy), second century BC, the surfaces of the walls are filled with a rich variety of scenes blending mythology and everyday life. Painted figures dialogue with each other across the walls: they look and point at each other. A sense of involvement strikes the visitors as they find themselves literally surrounded by these exchanges and by the events that are portrayed on the walls (the Dionysian initiation ritual that constitutes a core element of this set of paintings is probably the strongest of these exchanges). The gazes that the painted characters exchange from one side of the room to the other are here the core tools through which a sense of immersion is generated in the viewers. In an on-going fading of 'the borders between visual and actual space' (Grau 1999: 365) viewers become part of the painting and the world that it portrays, while the image starts appearing as 'a portal through which in one direction the gods pass into the real world and in the other real people enter into the image' (Grau 1999: 366).

The Ara Paci Augustae in Rome (an altar dated around thirteen BC dedicated to Pax, the Roman goddess of Peace,) offers us another kind of immersive visuality. The internal space of the altar is shaped through a merging of bas-relief, depicting scenes from mythology and elements of nature (mainly leaves) that are inserted in and on the walls. While Pompei (and Herculaneum ) are unique examples of the Roman use of painting on internal walls, the bas-relief and sculptures of Ara Pacis are more typical techniques 
that ancient Roman artists and architects used for exploiting the space represented by the walls. Giulio Carlo Argan (2008) has suggested that the Romans did not experience the wall 'as a solid surface, but as a spatiality or imaginary depth' (Argan 2008: 147). Presenting a 'hypothetical space, a plane of projection' (Argan 2008: 147) the wall was for them not a boundary, but a joint, a juncture, a portal between physical natural space and pictorial space. The use of stucco would later on insert such spatial experiences also in the context of painting. It allowed for the creation of thick, modulated surfaces allowing views to explore a multiplicity of angles from which to observe the image, and of allowing actual life (in the shape of light and shadows) to mix with the visual impressions generated by the objects represented in the image.

The Roman Catholic and Greek Orthodox churches designed under the influence of Byzantium, offer insights into yet another immersive technique, this time based upon a blend of materiality and composition. The Mausoleum of Galla Placidia in Ravenna (fifth century $\mathrm{AD}$ ), to give but one example, embraces the viewers with visual details that are placed all over the walls. The use of mosaic in particular, with its variety of different materials capable of absorbing and defracting light, have a deceiving and displacing effect on the viewers. Similar to Roman stuccos, it deceives viewers' perceptions of the dimensions of the space in which they find themselves, hence leading to a transcendence of physical space altogether (see Argan 2008). As Greek Orthodox churches still make evident today, worshippers are also surrounded by a broader set of sensory experiences; by the glittering lights generated by candles mirrored on the metal and the glass tiles composing the image, by the smell of incense, and the sound of the bells. This exposure to a full sensorial experience brings viewers, through their senses, in touch with the divine.

21 I could go on giving more examples from Antiquity but let us instead observe how a quest for immersivity is also characteristic of modern practices. Stereoscopic images were created at the very dawn of photographic history. Along with panoramic formats these expressed a concrete attempt of moving as far as possible away from the limitations imposed by the square, narrow frame provided by the first cameras. These were used to awaken physical reactions towards a landscape or of arousal towards erotic or even pornographic imagery (Gilardi 2002).

Cinema too responded to the same craving for immersion (and for a dynamic environment in which to move) with 3D movies. Supposedly born in response to the possibilities offered by sound for surrounding the viewer (see Elsaesser 2013), 3D cinema speaks, according to Akira Mizuta Lippit (1999), of a desire to overcome the limitations to perception imposed by screens and frames. In Thomas Elsaesser's (2013) words, this is an attempt to 'self-abolish' the 'apparatic scaffolding and peculiar geometry of representation' (Elsaesser 2013: 229). 3D cinema (as well as following formats such as IMAX) can, therefore, be seen as direct precursors of VR, introducing 'the malleability, scalability, fluidity, or curvature of digital images into audiovisual space' (Elsaesser 2013: 235). The list of examples could go on with the experiences of Cubism, Dadaism, and Futurism, which were all characterized by an attempt at converging on the same canvas multiple angles or moments of observation. It could also move further into the world of the video installations of Ken Jacobs and Bill Viola or of the 3D laser-mapping installations of Danny Rose or of Miguel Chevalier. All these works, I suggest, despite the diversity of techniques deployed, are united by the desire of overcoming the separation between the observer and the observed, the ' $\mathrm{I}$ ' and the 
world typical of flat images. We can however grasp a more detailed insight into this yearning by taking yet another leap backwards and exploring the principles that underpin Byzantine art inspired icons.

\section{The Transformative Visuality of Icons (and of $\mathrm{Vr} / \mathrm{Mr}$ ?)}

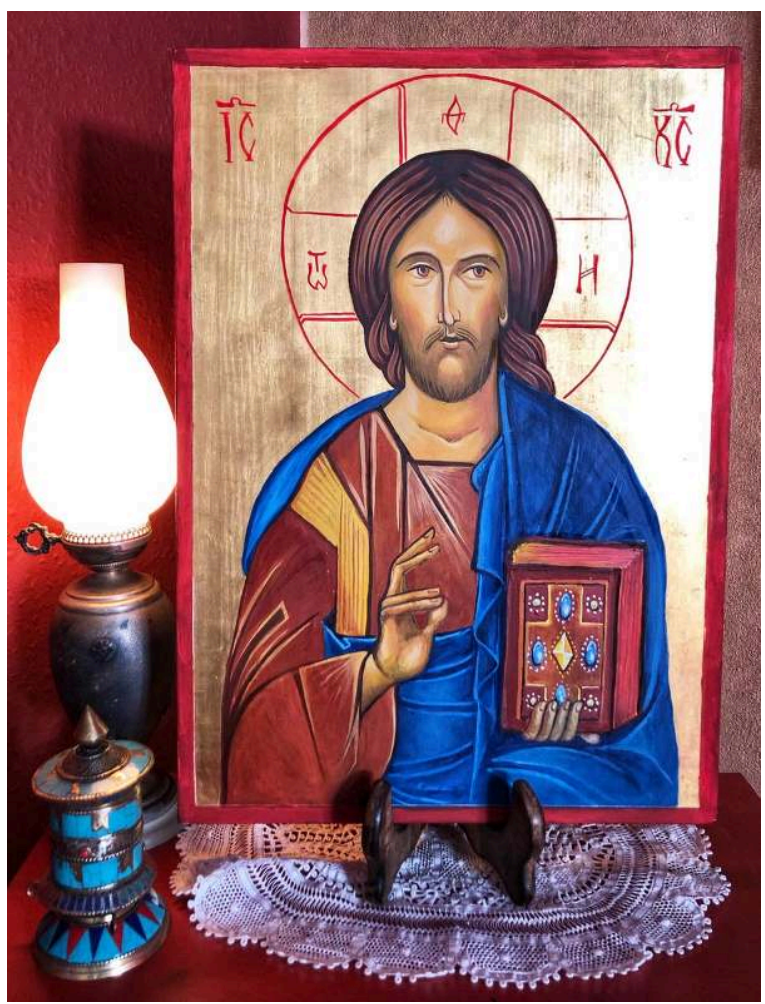

Icon painted by Sr. Silvia Favero.

Photograph by Paolo S.H. Favero.

one of their key characteristics the resistance to comply to one single type of mathematical reduction (as in the case of geometrical perspective). They are constituted by a combination of techniques of composition as well as of material production, that contribute in offering the viewers multiple (and sense-driven) points of entry. Supported by a specific spiritual vision such pictures are dynamic, allowing viewers to observe them literally as well as metaphorically from a variety of perspectives.

The first thing to notice when we enter the visuality of icons is that these are neither fully bi- nor fully tri-dimensional images (Lindsay Opie 2014). Icons are conventionally characterized by what is commonly referred to as 'reverse perspective' (Pencheva 2010; Argan 2008; Florensky 1967; Marci 2014). ${ }^{7}$ Rather than being unaware of the principles of geometrical viewing, Byzantium painters and mystics seem to have developed a different (perhaps 'parallel') spatialization of the relationship between the image and the viewer. In terms of design techniques, these images are divided into two main layers. The front layer, the one where the face of the divinity is portrayed, is conventionally positioned on a flat surface, frontally facing the viewer. The rest of the image (starting from the head and the hair, to the aura and the background) is instead 
characterized by a rounded shape which is designed according to the above-mentioned principle of reverse perspective which has its own vanishing point behind the viewer (Sendler 1985). ${ }^{8}$ Through this composition of foreground and background, viewers are simultaneously frontal to the face of the divinity while also being while being wrapped into it. As art historian Bissera Pencheva (2010) has suggested, the 'picture space' of an icon 'opens up in front of the image rather than behind it' (Pencheva 2010: 6). ${ }^{9}$

There is however more to the icon, which adds to its magnificent complexity. The result of the use of not only colours but also metals, icons shine, often causing the viewers to mirror themselves in them. Their golden background offers in fact no representational context. The divinity does seldom appear surrounded by objects or landscapes. Instead, it invites viewers to mirror themselves and their own context of viewing in the picture. In this sense icons are truly reflexive images. The thin golden foil that makes up their background is meant to bring the viewer in direct touch with the divine figure portrayed: 'instead of the light reflected from the outside world we find uniform gold, thanks to which the image itself becomes an independent source of light' (Lindsay Opie 2014: 146). Symbolizing 'pure divine light' (Sendler 1998) the golden foil is to be understood within the spiritual view that sustains icons. It is also informed by a visuality defined by the theory of 'extramission' whereby 'the eye was active, sending off rays that touched the surfaces of objects' (Pencheva 2010: 5). It is, hence, neither illustration nor decoration, but a tool for communicating directly with the realm of the divine (of the invisible) and for entering it. There is no subjectivity involved by the painter here. He or she is just a conduit towards 'a true participation at the world of divine archetypes' (Lindsay Opie 2014: 146). A form of 'sustained dream' (Florensky 1977: 34), icons, like spiritual art in general, grant according to Pavel Florensky access to a 'world upside-down' (Florensky 1977: 31). They lift up the soul from earthly matters bringing it in touch with another dimension (the 'celestial' one). Florensky suggests that this world (with its 'curvatures', that is its spiritual essence) manifests itself only through the interaction with the viewer, behaving, to use his metaphor, like 'a magnetic field on top of a surface that gets visible only by pouring metal dust' (Florensky 1977: 52). Unlike Western perspectival painting icons are 'the cliff of celestial figures ... Icons materially sign these penetrating and immemorial gazes, these super-sensual ideas, making inaccessible visions almost public' Florensky 1977: 64). The strength of icons, Egon Sendler suggests, lies in their capacity to be 'images of the invisible' (1985). Other types of icons do also explore the use of materiality even further. In the past in particular they have been produced in relief or constructed with the help of materials whose texture would provide the viewer with a sense of direct tactile engagement. Pencheva (2010) states that the icon is a matter of 'tactile visuality' (Pencheva 2010: 6, 7), that is sensorially experienced.

My main point however is that icons, despite their figurative centre (an image of Christ, of the Virgin Lady, etc.) have as their primary mission not that of representing but rather of taking the worshippers elsewhere, to transform them through vision. Through artefacts such as icons, art provides human beings with a connection between the visible and the invisible world. Just like Hindu devotional images, such icons are therefore not a mere representation of something out there but an entry into another experiential dimension. Objects of 'visual ascesis' (Lindsay Opie 2014) they speak of presence, contemplation and transformation rather than narration. In a movement that goes in the opposite direction from the Renaissance perspective, these techniques position viewers in the co-presence of possible parallel worlds (the parallel with 
Buddhist nonduality is here evident). I could go even further into my exploration of the visuality of Byzantium icons, but I guess that what I have written so far may suffice to open up room for my parallel with the world of VR and MR. In the context of VR the body is in fact central, interpellated by a series of act that simultaneously connect and disconnect the viewer to the image and its content. The body is foregrounded not as a mere 'appendage to the self' (Dolezal 2009: 209) but rather as the core tool through which any form of engagement with the world is made possible. They seem to materialize Merleau-Ponty's (1962) above-mentioned intuition that humans can only be and know themselves 'in the world' (Merleau-Ponty 1962: xi). Such images also foreground a degree of interactivity, asking viewers to actively engage with and move within the depicted space. With their multiple short-circuits of mind and body they provoke instances of dissociation, hence transforming the viewers, re-inserting them in their actuality often (and at least temporally) in a new position..$^{10}$ It is of little surprise that VR experiences are today explored in medical settings for the treatment of posttraumatic stress syndrome, eating disorders, panic attacks etc.

\section{Conclusions}

The possible dialogues between the worlds of VR/MR and that of icons may indeed not be explicit. Yet, they surely speak of the manifold ways in which humans have attempted at using images in order to enter the world in which they live and to transforms themselves. We could also imagine that the visuality that characterizes the world of icons may also have directly inspired contemporary artists. It is after all part of the cultural heritage of our world. But regardless of the interpretation we want to give to this dialogue, the parallels between these different regimes of visuality are many, as they both address matters of interactivity and multisensoriality. Both also move away from a pure representational duty towards a contemplation and a transformative act of presencing. Taking us away from narration and realist representation they move towards that sense of oneness between the human and the world that makes up the fundament not only of Saint Augustine's intuitions but also of many other knowledge systems, such as Buddhism, Hinduism, and various forms of animism (see von Glanesapp 1967; Tucci 1992; Knott 1999). The suspension of the distinction between the observer and the observed and between the self and the world combined with a sense of detached observation and acceptance of the world surrounding us is, in fact, a core coordinate in the practice of meditation (see Easwaran 1978).

Such visualities seem, hence, to move against the hegemonic trends of Western visual culture that I described earlier. Disrupting the geometrical-political conventions that characterise conventional understandings of camera-produced images, they threaten the assumptions that we have inherited from the Renaissance perspective and that have been consolidated by photography and film. A step into the elsewhen and the elsewhere can hence help us grasping such contemporary digital visual practices in a new terrain hopefully able to contribute in decolonizing our overall understanding of visual culture. 


\section{BIBLIOGRAPHY}

\section{Books and articles}

Argan, Giulio Carlo. 2008. Storia dell'Arte Italiana: Dall'Antichita' al Medioevo. Milano: RCS Libri.

Babb, Lawrence A. 1981. Glancing: Visual Interaction in Hinduism. Journal of Anthropological Research 37(4): 387-401.

Barthes, Roland. 1993. Camera Lucida, trans. Richard Howard. London: Vintage Publishing.

Batchelor, Steven. 1998. Buddhism without Beliefs: A Contemporary Guide to Awakening. London: Penguin.

Bazin, André. 1960. The Ontology of the Photographic Image. Film Quarterly 13(4): 4-9.

Didi-Huberman, Georges. 2003. Images in Spite of All: Four Photographs from Auschwitz, trans. Shane B. Lillis. Chicago and London: The University of Chicago Press.

Dolezal, Luna. 2009. The Remote Body: The Phenomenology of Telepresence and Re-Embodiment. Human Technology an Interdisciplinary Journal on Humans in ICT Environments 5(2): 208-226.

Easwaran, Eknath. 1978. Meditation: Commonsense Directions from an Uncommon Life. London: Routledge.

Eck, Diana L. 1998. Darsan: Seeing the Divine Image in India. New York: Columbia University Press.

Edwards, Elizabeth. 2005. Photographs and the Sound of History. Visual Anthropology Review 1 \& 2: 27-46.

Elsaesser, Thomas. 2013. The 'Return' of 3-D: On Some of the Logics and Genealogies of the Image in the Twenty-First Century. Critical Inquiry 39(2): 217-246.

Favero, Paolo S. H. 2018. The Present Image: Visible Stories in a Digital Habitat. Basingstoke: Palgrave MacMillan.

Florensky, Pavel. 1977. Le porte regali, trans. Elémire Zolla. Milano: Adelphi.

Frazer, James G. [1890] 2009. The Golden Bough: A Study of Magic and Religion. Portland, Or.: The Floating Press.

Freud, Sigmund. [1919] 1925. The ‘Uncanny’ Imago, trans. Alix Strachey. Available online: https://web.mit.edu/allanmc/www/freud1.pdf (accessed 16 February, 2019).

Gilardi, Ando. 2002. Storia della fotografia pornographica. Milano: Mondadori.

Gramsci, Antonio. 1971. Selections from the Prison Notebooks of Antonio Gramsci. Quintin Hoare and Geoffrey Nowell Smith, eds. and trans. New York: International Publishers.

Grau, Oliver. 1999. Into the Belly of the Image: Historical Aspects of Virtual Reality. Leonardo 32(5): 365-371. (Seventh New York Digital Salon).

Ito, Mizuko. 2005. Intimate Visual Co-Presence. International Conference on Ubiquitous Computing, UbiComp 2005, Tokyo, Japan. www.itofisher.com/mito/archives/ito.ubicomp05.pdf (accessed 5 May, 2015).

Jay, Martin. 1988. Scopic Regimes of Modernity. In Vision and Visuality. Hall Foster, ed. Pp. 3-23. Seattle: Bay Press.

Kandinsky, Wassily. 1989. Lo spirituale nell'arte, trans. Elena Pontiggia. Milano: Brossura. 
Khosravi, Shahram. 2018. Walling, Unsettling, Stealing. Keynote at EASA conference 2018. https://www.easaonline.org/conferences/easa2018/ (accessed 28 February, 2019).

Knott, Kim. 1999. Induismo. Torino: Einaudi.

Lindsay Opie, John. 2014. Nel Mondo delle Icone: dall'India and Bisanzio. Milano: Jaca Books.

Lippit, Akira Mizuta 1999. Three Phantasies of Cinema - Reproduction, Mimesis, Annihilation. Paragraph 22 (November): 213-214.

Marci, Tito. 2014. Codificazione artistica e figurazione giuridica: dallo spazio prospettico allo spazio reticolare. Torino: G. Giappichelli Editore.

Merleau-Ponty, Maurice. 1962. Phenomenology of Perception, trans. Colin Smith. London: Routledge \& Kegan Paul.

Milgram, Paula, Haruo Takemura, Akira Utsumi, and Fumio Kishino. 1994. Augmented Reality: A Class of Displays on the Reality-Virtuality Continuum. Proceedings of SPIE - The International Society for Optical Engineering 2351: 282-292. DOI: 10.1117/12.197321. https://www.researchgate.net/ publication/228537162_Augmented_reality_A_class_of_displays_on_the_realityvirtuality_continuum (accessed 28 February, 2019).

Pencheva, Bissera. 2013. The Sensual Icon: Space, Ritual, and the Senses in Byzantium. University Park, PA: Penn State University Press.

Pinney, Christopher. 2001. Piercing the Skin of the Idol. In Beyond Aesthetics. Christopher Pinney and Nicolas Thomas, eds. Pp. 157-179. London et al.: Bloomsbury Academics.

Sendler, Egon. 1985. L'Icona: Immagine dell'Invisibile. Milano: Edizioni San Paolo.

Shaw, J. L. 1978. Negation and the Buddhist Theory of Meaning. Journal of Indian Philosophy 6(1): 59-77

Stafford, Barbara Maria 1996. Good Looking: Essays on the Virtues of Images. Cambridge, MA: The MIT Press.

Tucci, Giuseppe. 1992. Storia della filosofia Indiana. Bari: Laterza.

Von Glasenapp, Helmuth. 1967. Indiens Religioner. Lund: Studentlitteratur.

\section{Performance}

Tannahill, Jordan (dir.) 2019. Draw Me Close. Production: National Theatre's Immersive Storytelling Studio and National Film Board of Canada.

\section{NOTES}

1. 'Mixed reality' is an overarching term conventionally used for addressing visualizations where physical and digital objects co-exist and interact in real time. We could place this term at any given point within the continuum that goes from the 'real' to the 'virtual.'

2. This article is dedicated to my aunt, Suor Silvia Favero, amazing artist, loving and enlightening presence who introduced me to the world of religious icons.

3. I am indebted to the writings of Christopher Pinney for the discovery of Stafford's work.

4. Draw me Close is in a co-production between the National Theatre's Immersive Storytelling Studio and the National Film Board of Canada, in collaboration with All Seeing Eye. The trailer can be seen at https://www.youtube.com/watch?v=4zokAxgRNYs and a further analysis at https://www.youtube.com/watch?v=XrpUvRSb2E0 
5. https://www.youtube.com/watch?v=odcsxUbVyZA\&t=13s

6. The term Buddhist philosophy (as well as Buddhism) does not really adapt to describing the corpus of knowledge that makes up the teachings that are conventionally attributed to the figure of the Buddha. Nevertheless, I will use it here for lack of better options warning however the reader about the epistemological traps embedded in conventional choices of terminology.

7. Thank you Tito Marci for introducing me to the world of reverse perspective.

8. There is indeed a debate among art historians and icon painters as to whether the vanishing point is located behind the viewers or at the height of their eyes.

9. If we were to look even further into the visuality of the icon we could state that, in its overlap of foreground and background, it also offers a visuality explainable only within the logic of Buddhist double negation: neither inside nor outside.

10. I have been able to observe this together with my colleague Eva Theunissen with whom I conducted ethnographic observations and interviews with VR viewers.

\section{ABSTRACTS}

In the context of contemporary digital art and documentary making, practitioners are discovering the possibilities given by emerging image-based immersive practices, techniques and tools (360-degree video and photography; virtual, augmented, and mixed reality) to wrap viewers in the image and to blur the distance between viewer and viewed, 'self' and 'other'. Challenging the distinction between presence and absence and between body and mind, these practices also seem to attack another set of divides, i.e. between past and present, here and there. An intrinsic part of late-modern, industrial, capitalist societies new experiences in immersive visual documentary and art (MR and VR especially) contain traces of continuity with the visualities that characterise other (non-modern) places and times. They share some of the core principles that characterise the visuality of, for instance, Byzantine icons, as well those of Hindu popular religious art. Based on the concrete analysis of a selected number of examples gathered form the world of contemporary MR and VR performance art this article suggests that art is always the result of a dialogue across the elsewhere and the 'elsewhen'. Underpinning this article is also the idea that an act of decolonisation of knowledge, enacted by means of the use of categories imported from other epistemologies (such as Byzantine and Hindu image theory as well as Buddhist philosophy) can help us look at contemporary emerging arts and documentary practices with new eyes.

Les praticiens de l'art numérique contemporain et des documentaristes découvrent les possibilités immersives fondées sur les images, techniques et outils (per exemple 360-degrés vidéo et photographie ; réalité virtuelle, augmentée et mixte) servant à inclure l'observateur dans l'image, et de brouiller ainsi la distance entre observateur et observé, entre soi et monde. Étant donné que ces pratiques défient la distinction entre présence et absence, elles semblent aussi s'attaquer à d'autres dualités, comme celle entre passé et présent, ici et là-bas. Ces nouvelles expériences en arts visuels immersifs apparaissent comme intrinsèques des sociétés capitalistes industrielles de la modernité tardive. Pourtant, ces arts portent tout autant des traces de continuité avec des visualités qui caractérisent d'autres lieux (non-modernes) et époques. Ils partagent, par exemple, des principes de base de la visualité avec les icônes Byzantines, ou avec l'art religieux populaire Hindou. Fondé sur l'analyse d'exemples concrets du 
domaine de l'art de la performance contemporain e MR et VR, cet article propose que l'art serait toujours le résultat d'un dialogue avec un autre lieu et un autre temps. Une autre idée est sousjacente : promulgué e par l'utilisation de catégories importées d'autres épistémologies (telle que la théorie de l'image Byzantine et Hindoue, ou de la philosophie Bouddhiste), un tel acte de décolonisation de connaissances permettrait un nouveau regard sur les arts contemporains émergeants et les pratiques documentaires.

Este artículo presenta una propuesta metodológica para el trabajo entre la antropología y las artes que se basa en la relación entre la forma social y la forma estética. Parte del trabajo de los autores con los editores cartonera en América Latina. Éstos son pequeños colectivos comunitarios cuyos miembros fabrican libros de bajo coste a partir de cartón reciclado en un intento explícito de hacer que el consumo y la producción de literatura sean accesibles para la sociedad en general. Comenzamos describiendo a Dulcinéia Catadora, una editora de cartonera de São Paulo que es el foco etnográfico de este artículo. Luego presentamos tres proposiciones teóricas que nos permiten analizar los procesos sociales y políticos no de manera aislada, sino más bien en relación, preguntando cómo la práctica etnográfica puede cruzarse con la estética en un modo que va más allá de lo ilustrativo. Concluimos proponiendo lo que llamamos un enfoque metodológico "trans-formal", basado en un método de "emulación", que abre nuevas posibilidades para una investigación multidisciplinaria, transnacional, horizontal y participativa.

\section{INDEX}

Palabras claves: estética, política, metodología, trans-formal, cartonera, América Latina

Keywords: virtual reality, mixed reality, visuality, decolonization of knowledge, visual culture, digital culture

Mots-clés: réalité virtuelle, réalité mixte, visualité, décolonisation de la connaissance, culture visuelle, culture numérique.

\section{AUTHOR}

\section{PAOLO S. H. FAVERO}

University of Antwerp, Visual and Digital Cultures Research Center (ViDi)

paolo.favero@uantwerpen.be 